\title{
THE USE OF SWEAR WORDS IN PEWDIEPIE'S YOUTUBE VIDEOS
}

\author{
Octavia Wulandari \\ UIN Aluddin Makassar \\ ovwulan@gmail.com
}

\begin{abstract}
This research discussed about, the use of swear words uttered by PewDiePie's in his Youtube Videos which aimed to show the types of swear word found in the PewDiePie's videos, and to show the dominant types of swear words based on the meaning and meaningless swearing. This research was descriptive qualitative method. The object of the study were five videos from Pewdiepie's Youtube channel which collected based on most viewed videos on his Youtube channel. The researcher used note taking as the instruments in order to get the valid data. The findings showed that there were five types of swear words that used in PewDiePie's videos those were: 14 data of Dysphemistics, 38 data of Idiomatically, 1 data of Abusively, 24 data of Emphatically, 27 data of Carthartically. The researcher conclude that the dominant type of swearing that Pewdiepie used in his videos is SW2 which does not have any intrinsic meaning at all (categorized as Emphatic swearing and Idiomatic swearing) rather it is merely a word that could express the feeling towards other people without offend someone's pride.
\end{abstract}

Keywords: Swear words; Pewdiepie; Youtube

\begin{abstract}
Abstrak
Penelitian ini membahas tentang, penggunaan kata-kata umpatan yang diucapkan oleh PewDiePie dalam Video Youtube-nya yang bertujuan untuk menunjukkan jenis kata umpatan yang ditemukan dalam video PewDiePie, dan untuk menunjukkan tipe kata umpatan yang dominan berdasarkan makna dan sumpah tanpa arti. Penelitian ini merupakan penelitian deskriptif kualitatif. Objek penelitian ini adalah lima video dari saluran Youtube Pewdiepie yang dikumpulkan berdasarkan video yang paling banyak dilihat di saluran Youtube-nya. Peneliti menggunakan catatan sebagai instrumen untuk mendapatkan data yang valid. Temuan menunjukkan bahwa ada lima jenis kata umpatan yang digunakan dalam video PewDiePie yaitu: 14 data Dysphemistics, 38 data Idiomatically, 1 data Abusively, 24 data secara emosional, 27 data Cartrama. Peneliti menyimpulkan bahwa jenis sumpah yang dominan yang digunakan Pewdiepie dalam videonya adalah SW2 yang sama sekali tidak memiliki makna intrinsik (dikategorikan sebagai sumpah Emphatic dan sumpah Idiomatik), melainkan hanya sebuah kata yang bisa mengungkapkan perasaan terhadap orang lain tanpa menyinggung kebanggaan seseorang.

Kata kunci: Kata Umpatan; PewDiepie; Yuotube
\end{abstract}

\section{INTRODUCTION}

Swearing is an interesting aspect of language, which involves emotional and linguistic expression. It exists in most people's repository, but is also lead by a certain degree of taboo. Contrary from language in general, swearing is not typically taught by important figures like parents, or in school, but is rather picked up from peers or figures with a different kind of authority (for example idols in sports or television). To most people, swearing has negative connotations and is seen as bad language; something ugly, not appropriate, and is associated with low social class and low 
prestige. Despite this, Andersson \& Trudgill (1992:195) states that swearing has an important role in children's cognitive and social development and therefore should be encouraged within the right contexts.

In recent time the use of profane language is not the same from past. Formerly, when somebody shouted a swear word at people in front of public, it was considered that he wanted to bomb whole people around there. People could not accept his attitude through the language that he used. They were shocked, angry, hurt, offended and disgusted when they heard bad language. Allan (2001:148) proposes the definition of swear words. 'Swear words are those considered offensive, shocking, or indecent when use in certain context, there are strict conditions on their use and penalties for violating these conditions'.

Nevertheless, the worst part is many people use swearing without thinking, remorse and without even realizing that these words are obscene, filthy or repulsive using four letter words in every sentence and in every conversation. In recent time, people are faced with the swear words which almost appear in daily conversation. It is recognized that swearing is a deliberately bad act, designed for emotional expression. There are many types of swear words, in which every type has different meanings and purposes in spoken language. In addition, Andersson and Trudgill (2007:195) define swearing as language use in which the expression: (i) refers to something taboo or stigmatized in the swearer's culture, (ii) is not intended to be interpreted literally, (iii) can be used to express strong emotions or attitudes. The combination of these aspects results in an expression with a greater expressive power. For this reason, swearing can be more functional in particular circumstances.

A specific context where swearing seems to be quite prevalent, is Social Media. Over the last decade, social media has become an integral part of our daily lives. According to the 2012 Pew Internet \& American Life Project report, 69\% of online adults use social media sites and the number is steadily increasing. Another Pew study in 2011 shows that $95 \%$ of all teens with ages 12-17 are now online and $80 \%$ of those online teens are users of social media sites. People post on these sites to share their daily activities, happenings, thoughts and feelings with their contacts, and keep up with close social ties, which makes social media both a valuable data source and a great target for various areas of research and practice, including the study of swearing.

The communication on social media has its own characteristics which differentiates it from offline interaction in the physical world. Let us take YouTube for example. Since the launch of YouTube in 2005, the world has been witness to an incredible community of user-generated content, with more than 72 hours of video being uploaded every minute.

One of popular users in YouTube is Felix Arvid Ulf Kjellberg also known by his online alias PewDiePie, who has more than 50,000,000 subscribers to his channel on YouTube, where he broadcasts videos of himself playing - and commentating on video games. In most of his videos PewDiePie often use swearing very commonly, in every situation influences people's thinking to convey his ideas in what form of 
language he would choose. As a result to this, PewDiePie is a good example to what swearing are use now, how will he choose his word carefully, according to whom he is talking to, how the relationship of him and the hearer is, what information that he would convey and the form of situation between the speaker and hearer is. The way to speak differently in different social contexts is studied through sociolinguistics.

In this research the main focus is on swearing. Besides, swearing seems to be very common on YouTube. It takes only little time browsing the website to find swearing comments like "BURN IN HELLL!!!" and "F*ck" "Sh*t*, etc. Though not all swearing is the same: There are many different forms and types of swearing that have been described. One the one hand, swearing (SW1) may be a display of (intentional) impoliteness, serving verbal abuse, instrumental aggression and power hierarchy building among anonymous internet users. On the other hand, swearing (SW2) may have a non-referential definition (Fairman 2006: 45). In this thesis, the writer is interested in analyzing the use of "swearing words" in PewDiePie's video using a sociolinguistic approach, in order to find the use of "swearing words" in YouTubers Community.

\section{PERTINENT IDEAS}

\section{Taboo and Swearwords}

Taboo word has close relationship with swear words. It is because swear word is considered indecent and inappropriate in polite contexts, exists in most languages and cultures when linguistic taboos arise from social taboos (Andrew Grey: 2011-1). And swear word is part of taboo words because every people who use swear word is almost use taboo words inside. According to Michael Swan (1995:550), taboo words and swear words are shock less. Peter Trudgilll stated, "breakin the rules (may) have connotations of strength or reeedom which (people) find desirable. besides it could be also "largely because taboo words are frequently used as swear -words, which is in turn because ther are powerful.

According to David Chrystal (2003), swearing refer to the strongly emotive use of a taboo word or phrase, and he adds the word "use" is perhaps too weak because swearing is an aoutburst, anexplosion which gives relief to surges of emotional energy. The uniquely human facility for swearing evolved and persists because taboo words can communicate emotion information (anger, frustration) more readily that nontaboo words, allowing speakers to achieve a variety of persona and social goals with them (utility).

In this case, the words associated with religion are not cosidered shicking when it is used with their literal meaning but the word will show the strength when used as swear words. The strength of the other words is mostly the same whether they are used literally or for swearing.

Swear word is a reaction of word for something that is not favored. This is usually happened when someone starts to say a word beyond people patience in comonly. They can not control their emotions then people will say the swear words. According to David Chrystal (2003:173), swear word is an outburst, an explotion 
which gives relief to surges of emotional energy. It is a subtitute for an aggressive bodily rsponse, and can be aimed either at people or object.

According to Allan and Buridge (2005:303), swear word is response of frustation, pain and anger. A swear word is not just "a word like any other", people who suffer a loss of speech becase of damage to the language processing parts of their brain often retain the ability to curse. For example, becase swearwords are processed in the brain's limbic system, the area responsible for emotions. Moreover, Michael Swan adds that swear words are strong language that expressed by person to their powerful emotion. Generally, this expression comes from taboo word that literally same.

\section{Types of Swearwords}

Swearing words are unusual word in that it can be used as many different parts of speech. It can be used as a noun, adjective, adverb, or interjection. In fact, it can be used as practically any word in a particular sentence such as $F^{* * k}$ the $f^{* * k i n g}$ $f^{* * k e r s}$ or The $f^{* * k i n g} f^{* * k e r ' s} f^{* * k e d}$, as spoken by a garage-owner passing judgment on an old car (Ljung 2011: 40). Also, it is one of the few words that can be utilized as an infix in words such as Absof**kinglutely and Inf**kingcredible, $S^{* *}$ ttyhole and even as an expletive slot filler inside non-clausal units such as noun phrases, as in Henry the f**king Eighth (Ljung 2011: 143).

Jay and Janschewitz (2008) distinguish between automatic (unconscious, reflexive) versus more consciously controlled forms of swearing. Moreover, Jay (2009) argued that swearing can be characterized on a continuum from unconscious/automatic to fully conscious/controlled. Certain neurological disorders (e.g. Gilles de la Tourette syndrome) are associated with uncontrollable swearing in more extreme forms, but this form of swearing appears less functional.

Pinker (2007:323) even distinguishes at least five different types of swearing:

1) Dysphemism (Let's fuck)

Is the exact opposite of euphemism (polite expression used in place of words or phrases that otherwise might be considered harsh or unpleasant to hear). It forces the listener to think about things in a negative or provocative matter.

Using the wrong euphemism has a dysphemistic effect, is the process whereby the most pejorative traits of the swearing are highlighted with an offensive aim to the addressee or the audience, or to the concept itself. Dysphemisms, are used in talking about one's opponents, things one wishes to show disapproval of, and things one wishes to be seen to downgrade. e.g. calling someone using "Looney Bin" in place of mental hospital. Using "Faggot" in place of homosexual.

2) Idiomatically (It's f*cked up.)

Is swearing without really referring to the matter. People who use this type of swearing are just using the words to arouse interest, to show off or to express to peers that the setting is informal. Idiomatic swearing, is another possible reason as to why someone might swear. It is used to gain attention, used to arouse interest in a certain matter or appear macho. This can be used to 
express dominance or strengthen a relationship, (e.g. pain in the ass, fuck, man and hell, yeah.)

3) Abusively (F*ck you, motherf*cker!!)

Abusive swearing is just that; it is directed towards someone else in a derogatory manner whether in an argument, heated debate or just plain rude behavior and is used for the abuse, intimidation or insulting of others. Some of the popular abusive words that are mostly used include "fuck you" and "son of a bitch"

4) Emphatically (This is f*cking amazing!)

Is swearing to emphasize something either by describing its size, stature or relationship to things around it. Emphatic swearing is used to assert emphasis about a certain issue or matter. A person can be emphatic about a point by swearing. For instance, this food is fucking delicious and you are fucking stupid. These are two examples of emphasizing something by swearing.

5) Cathartically (F*ck!!!)

Provides the user some much needed psychological relief through the open expression of strong emotions. This gives the user some form of short term relief from a stressful situation. This type of swearing is usually heard when something bad happens like coffee spilling. One evolutionary theory asserts it is meant to tell the audience that you're undergoing a negative emotion.

Cathartic swearing is used when something that displeasing happens, for instance, when a person gets hurt or feels bad. Cathartic swearing is used to reveal to an audience that a person is undergoing a difficult time or is experiencing negative emotions. For instance, a person can swear by stating Aww, fuck! Damn this coffee.

\section{PewDiePie (Felix Kjellberg)}

In recent years there has been an astounding rise of YouTube personalities interacting with people in terms of gameplay showcases, reviews and satirical shows. These online productions have reached such notoriety now that they actively affect the industry that they initially were a part of; one of the most prominent examples being PewDiePie (YouTube, 2015). Real name Felix Kjellberg, PewDiePie is the most influential YouTubers ever with well over (as of 2016) 56 million subscribers to his channel and an avid fan base, referred to as his Bro Army.

It can be expected, with over 56 million viewers his videos blog a lot of weight in fanbases and the general populous. Using Diffusion of Innovation theory (E, Rogers, 2003), it can't be denied that PewDiePie is defined as an innovator; His funny hosts, off-the-cuff commentary, silly antics, and bewildering (to adults) subject matter put him among the most popular YouTube channels for young teens, garnering millions of views. In fact, according to a recent survey of U.S. teens by Variety, the top five most influential celebrities are YouTube stars. These YouTubers are now far more influential than average celebrities (B, Crecente, 2014 and C, Hall, 2014) and as 
such create a new variation of Fanboy, one that is just as vocal and loyal but also willing to change and absorb anything that their idols play.

But information about these personalities shows: the content, quality, and age-appropriateness, is not easy for society to accept it. Due to he is also swears very commonly, and is not afraid to outright state what he says, making fun of some of the games he plays. One of few quotes of him swearing in video: "You fu*king disgraaaace!" (To the little boy at the back of Irresponsible Dad's bike, 2013)

This leads to a surge of other popular personalities copying PewDiePie's behavior and their fans being showcased to his personalities as well.

\section{RESEARCH METHODOLOGY}

This research was a descriptive-qualitative research with a content analysis method. This study emphasized the importance of analysis performance of the writer and set out empirical observation that consists of descriptive and analyctical passages. Bogdan and Biklen (1992:28) delimit qualitative research as a research which is providing description of a phenomenon that occurs naturally without any intervention of an experiment or an artificially contrived treatment. By using this method the writer would be able to explain or describe the use of swearing that found on PewDiePie's video.

\section{FINDINGS}

To answer the first problem, firstly, this chapter referred the data presented in script of 5 videos. Then, exposed them into the table. In understanding the data, the writer presented explanation of types of swearword from the utterances as a transcript of swearword, which explained with context (time, addressed, topic). the writer also displayed the types of swearing words but devided in each table, which are (1) Dysphemism, swearing that have provocative meaning, (2) Idiomatically, swearing without really reffering to the matter, (3) Abusively, is swearing directed towards someone in derogatory manner, (4) Emphatically, is swearing is to describe something either by its size or things around it, (5) Cathartically, is the open expression of strong emotion that provides from the user. After that, the writer dividing the swearing into SW1 (meaning) and SW2 (meaningless) by using Fairman's theory (2006). In this step, the overall data were classified based on the research problems.

\begin{tabular}{|l|c|}
\hline \multicolumn{1}{|c|}{ Types of Swear Word } & Total \\
\hline Dysphemism & 14 \\
\hline Idiomatically & 38 \\
\hline Abusively & 1 \\
\hline Emphatically & 24 \\
\hline Cathartically & 27 \\
\hline \multicolumn{1}{l|}{} & 104 \\
\hline
\end{tabular}




\section{a. Dysphemism}

From the table 4.1, there were 14 swearing words which classified as dysphemism swearing out of $\mathbf{1 0 4}$ swearing data. In this analysis Pewdiepie used dysphemism swearing as expression offense either the subject matter or the viewers, or both.

\begin{tabular}{|c|c|c|c|c|}
\hline \multirow{2}{*}{$\begin{array}{l}\text { Number } \\
\text { of } \\
\text { Datum }\end{array}$} & \multirow{2}{*}{ Utterances } & \multicolumn{3}{|c|}{ Context } \\
\hline & & Time & $\begin{array}{c}\text { Addressed } \\
\text { \& Setting }\end{array}$ & Topic \\
\hline 22 & $\begin{array}{l}\text { Oh! Fuck me! } \\
\text { Okay. }\end{array}$ & $\begin{array}{c}00: 03: 37,550-- \\
>00: 03: 40,986\end{array}$ & $\begin{array}{l}\text { The situation } \\
\text { in hospital } \\
\text { (Hospital) }\end{array}$ & $\begin{array}{l}\text { He indicates that the situation } \\
\text { in the hopital was so scary, he } \\
\text { inserted the swearing with } \\
\text { deragatory manner and sound } \\
\text { rude too. }\end{array}$ \\
\hline 24 & $\begin{array}{l}\text { Okay! Okay! } \\
\text { Jesus Christ! } \\
\text { What the fuck! }\end{array}$ & $\begin{array}{l}00: 03: 54,933-- \\
>00: 04: 00,772\end{array}$ & $\begin{array}{l}\text { The girl who } \\
\text { approach him } \\
\text { (Hospital } \\
\text { Entrance) }\end{array}$ & $\begin{array}{l}\text { He let out the swearing in } \\
\text { negative manner because the } \\
\text { fear he felts, but he sound } \\
\text { rude towards the girl. }\end{array}$ \\
\hline 29 & $\begin{array}{l}\text { For fuck's } \\
\text { sake. }\end{array}$ & $\begin{array}{c}00: 06: 20,379-- \\
>00: 06: 21,614\end{array}$ & $\begin{array}{l}\text { The keys } \\
\text { (hospital } \\
\text { room) }\end{array}$ & $\begin{array}{l}\text { he inserted swearing words as } \\
\text { a protest of why the keys was } \\
\text { too far from him. }\end{array}$ \\
\hline 33 & $\begin{array}{l}\text { Oh, shit! What } \\
\text { the fuck are } \\
\text { you doing? }\end{array}$ & $\begin{array}{l}00: 08: 15,593-- \\
>00: 08: 17,529\end{array}$ & $\begin{array}{c}\text { The } \\
\text { wheelchair }\end{array}$ & $\begin{array}{l}\text { He found an automatic } \\
\text { wheelchair that can moved by } \\
\text { itself }\end{array}$ \\
\hline 37 & $\begin{array}{l}\text { Oh, fuck! } \\
\text { Fucking hell. }\end{array}$ & $\begin{array}{c}00: 09: 39,711-- \\
>00: 09: 46,851\end{array}$ & $\begin{array}{l}\text { The insects } \\
\text { (Chapel } \\
\text { room) }\end{array}$ & $\begin{array}{l}\text { The mission was to get the } \\
\text { handcam out of the box but } \\
\text { the box's full of insects, he let } \\
\text { out swearing in derogatory } \\
\text { manner. }\end{array}$ \\
\hline 40 & $\begin{array}{l}\text { What the fuck } \\
\text { are you? }\end{array}$ & $\begin{array}{c}00: 11: 06,465-- \\
>00: 11: 08,43\end{array}$ & $\begin{array}{l}\text { One of the } \\
\text { patient in the } \\
\text { hospitals } \\
\text { (Hospital } \\
\text { Entrance) }\end{array}$ & $\begin{array}{l}\text { Instead he used 'who are } \\
\text { you', he used 'what the fuck' } \\
\text { towards the patient. }\end{array}$ \\
\hline 45 & $\begin{array}{l}\text { What the fuck } \\
\text { is this? }\end{array}$ & $\begin{array}{l}00: 15: 16,148-- \\
>00: 15: 18,316\end{array}$ & $\begin{array}{l}\text { The paper } \\
\text { (Dr. Yate's } \\
\text { office) }\end{array}$ & $\begin{array}{l}\text { Instead he used what is this } \\
\text { he add fuck, when he read the } \\
\text { paper he found, he sound } \\
\text { disparage towards the paper } \\
\text { he found }\end{array}$ \\
\hline 61 & $\begin{array}{l}\text { What the } \\
\text { fuck? }\end{array}$ & $\begin{array}{c}00: 17: 38,222-- \\
>00: 17: 39,957\end{array}$ & $\begin{array}{c}\text { Kevin } \\
\text { (exit door) }\end{array}$ & $\begin{array}{l}\text { He didn't understand what } \\
\text { was the whole mission, he } \\
\text { was so confused to the point } \\
\text { he used swearing words } \\
\text { towards Kevin }\end{array}$ \\
\hline 66 & $\begin{array}{l}\text { you're fucking } \\
\text { wrong }\end{array}$ & $\begin{array}{c}00: 03: 22,439--> \\
00: 03: 23,400\end{array}$ & $\begin{array}{c}\text { The } \\
\text { commenter } \\
\text { (in his room) }\end{array}$ & $\begin{array}{l}\text { When he read the comment } \\
\text { he's like "i'm okay" but in } \\
\text { the end of his sentenced he } \\
\text { swearing. He swearing } \\
\text { towards the commenter and }\end{array}$ \\
\hline
\end{tabular}




\begin{tabular}{|c|c|c|c|c|}
\hline & & & & sound a bit angry. \\
\hline 72 & $\begin{array}{l}\text { That sleek son } \\
\text { of a bitch! }\end{array}$ & $\begin{array}{l}00: 01: 01,560-- \\
>00: 01: 03,420\end{array}$ & $\begin{array}{c}\text { Jake } \\
\text { Paul:youtube } \\
\text { rs } \\
\text { (PewDiePie's } \\
\text { office) }\end{array}$ & $\begin{array}{l}\text { He inserted swearing cause } \\
\text { he's angry Jake Paul dissed } \\
\text { him, and to sound more rude } \\
\text { he reply with swear words. }\end{array}$ \\
\hline 85 & Damn, damn, & $\begin{array}{l}00: 05: 28,439-- \\
>00: 05: 31,259\end{array}$ & $\begin{array}{l}\text { Jake Paul's } \\
\text { crew } \\
\text { (his office) }\end{array}$ & $\begin{array}{l}\text { Pewds inserted swearing } \\
\text { words to mocked JP'screw } \\
\text { about his rapping, and to } \\
\text { illustrated the whole situation }\end{array}$ \\
\hline 88 & $\begin{array}{l}\text { Dont make my } \\
\text { impression, } \\
\text { goddammit! }\end{array}$ & $\begin{array}{l}00: 00: 35,539-- \\
>00: 00: 37,460\end{array}$ & $\begin{array}{l}\text { Jack; his } \\
\text { friend } \\
\text { (In } \\
\text { Pewdiepie's } \\
\text { room) }\end{array}$ & $\begin{array}{l}\text { Pewds and his friend Jack, } \\
\text { was going to collaborated in } \\
\text { one video, Jack tried to } \\
\text { impersonated Pewds, so } \\
\text { Pewds inserted swearing } \\
\text { words towards Jack to stop } \\
\text { him making fun of him. }\end{array}$ \\
\hline 93 & $\begin{array}{l}\text { Shut the fuck } \\
\text { up! }\end{array}$ & $\begin{array}{c}00: 03: 07,900-- \\
>00: 03: 09,020\end{array}$ & $\begin{array}{c}\text { Jack } \\
\text { Camera no } \\
\# 2 \text { (on the } \\
\text { floor) }\end{array}$ & $\begin{array}{l}\text { Pewds inserted swearing to } \\
\text { stop Jack mocked him cause } \\
\text { Pewds losed in second round, } \\
\text { so Pewds said to Jack to shut } \\
\text { up. }\end{array}$ \\
\hline 101 & $\begin{array}{l}\text { Don't make } \\
\text { fun of my } \\
\text { fucking frog }\end{array}$ & $\begin{array}{l}00: 06: 45,360-- \\
>00: 06: 46,860\end{array}$ & Jack & $\begin{array}{l}\text { He inserted swearing to } \\
\text { defend his frog frm being } \\
\text { bullied by Jack }\end{array}$ \\
\hline
\end{tabular}

\section{b. Idiomatically}

From the table below, there were $\mathbf{3 8}$ swearing words which classified as idiomatically swearing out of 104 swearing data. Datum 3,4 $|\mathbf{9 , 1 3}| \mathbf{1 7 , 2 7 , 3 0 , 5 4} \mid$ 83,64 each of them are in the same collum. It was because these data did not require detailed analyses some of them were similar and repetitious, so the writer put them in the same collum. In this analysis the writer found that idiomatically swearing is the most widely used in the Pewdiepie's videos.

\begin{tabular}{|c|l|c|c|l|}
\hline \multirow{2}{*}{$\begin{array}{c}\text { Number } \begin{array}{c}\text { of } \\
\text { Datum }\end{array} \\
\text { Utterances }\end{array}$} & \multicolumn{4}{|c|}{ Context } \\
\cline { 3 - 6 } & & Time & $\begin{array}{c}\text { Addressed } \\
\text { \&Setting }\end{array}$ & \multicolumn{1}{|c|}{ Topic } \\
\hline $\mathbf{3 , 4}$ & $\begin{array}{l}\text { What the fuck } \\
\text { is this }\end{array}$ & $\begin{array}{c}00: 01: 22,799-> \\
00: 01: 24,239 \\
00: 01: 36,579-> \\
00: 01: 39,379\end{array}$ & $\begin{array}{c}\text { Towards the } \\
\text { boxes } \\
\text { in the living } \\
\text { room) }\end{array}$ & $\begin{array}{l}\text { The bolded sentences, indicates } \\
\text { that Pewds was curious about } \\
\text { the things inside the boxes, but } \\
\text { using swear words to make it } \\
\text { less formal. }\end{array}$ \\
\hline $\mathbf{9 , 1 3}$ & $\begin{array}{l}\text { That's really } \\
\text { fucking cool }\end{array}$ & $\begin{array}{c}00: 04: 49,199-> \\
00: 04: 50,500 \\
00: 06: 49,240-> \\
00: 06: 50,720\end{array}$ & $\begin{array}{c}\text { Towards the } \\
\text { Ruby button } \\
\text { (the living } \\
\text { room) }\end{array}$ & $\begin{array}{l}\text { He expressed the swearing } \\
\text { words to showed the ruby by } \\
\text { make it sound cool. }\end{array}$ \\
\hline $\mathbf{1 0}$ & $\begin{array}{l}\text { I know I shit } \\
\text { lot on } \\
\text { YouTube. }\end{array}$ & $\begin{array}{c}00: 05: 42,839- \\
>00: 05: 44,639\end{array}$ & $\begin{array}{c}\text { Youtube } \\
\text { (living room) }\end{array}$ & $\begin{array}{l}\text { He was remembering his past } \\
\text { before famous on Youtube and } \\
\text { how much he was grateful }\end{array}$ \\
\hline
\end{tabular}




\begin{tabular}{|c|c|c|c|c|}
\hline & & & & $\begin{array}{l}\text { towards youtube. He used this } \\
\text { term to make it more casual } \\
\text { and not sound so serious. }\end{array}$ \\
\hline 14 & $\begin{array}{l}\text { You're about to } \\
\text { vatch me get the } \\
\text { absolute shit } \\
\text { cared out of me }\end{array}$ & $\begin{array}{c}00: 00: 11,611-> \\
00: 00: 16,882\end{array}$ & $\begin{array}{l}\text { The viewers } \\
\text { (studio) }\end{array}$ & $\begin{array}{l}\text { He used swearing words for } \\
\text { intro of his video to gain more } \\
\text { attention of the viewers. }\end{array}$ \\
\hline 16 & $\begin{array}{l}\text { So if you love } \\
\text { watching me } \\
\text { get scared } \\
\text { shitless... }\end{array}$ & $\begin{array}{c}00: 00: 27,192-- \\
>00: 00: 29,795\end{array}$ & $\begin{array}{l}\text { The viewers } \\
\text { (studio) }\end{array}$ & $\begin{array}{l}\text { He inserted the swering words } \\
\text { without reffered anything he } \\
\text { just used it attract the viewers } \\
\text { and to sound less formal. }\end{array}$ \\
\hline $\begin{array}{l}\text { 17,27,30 } \\
, 54,\end{array}$ & $\begin{array}{l}\text { Fuck } \\
\text { (this/that) }\end{array}$ & $\begin{array}{c}00: 00: 29,861 \quad- \\
>00: 00: 32,330 \\
00: 05: 10,877-- \\
>00: 05: 12,244 \\
00: 06: 46,338-- \\
>00: 06: 47,507 \\
00: 17: 12,596-- \\
>00: 17: 15,966\end{array}$ & $\begin{array}{l}\text { The situation } \\
\text { in the } \\
\text { hospital } \\
\text { (hospital } \\
\text { room) }\end{array}$ & $\begin{array}{l}\text { He used the swearing words to } \\
\text { calm himself and the swearing } \\
\text { not } \\
\text { really reffered the matter }\end{array}$ \\
\hline 28,46 & $\begin{array}{l}\text { This is fucking } \\
\text { bullshit. }\end{array}$ & $\begin{array}{c}00: 05: 19,050-- \\
>00: 05: 20,652 \\
00: 15: 18,383-- \\
>00: 15: 20,719\end{array}$ & $\begin{array}{l}\text { The handcuff } \\
\text { (hospital } \\
\text { room) }\end{array}$ & $\begin{array}{l}\text { The doctor handcuff and leave } \\
\text { him alone, he inserted the } \\
\text { swearing as if he couldn't } \\
\text { believe what just have } \\
\text { happened. }\end{array}$ \\
\hline 35 & $\begin{array}{l}\text { Oh, shit! What } \\
\text { the fuck is this } \\
\text { doing here? }\end{array}$ & $\begin{array}{c}00: 08: 53,599-- \\
>00: 08: 57,169\end{array}$ & $\begin{array}{c}\text { The } \\
\text { wheelchair } \\
\text { (Hospital } \\
\text { Entrance) }\end{array}$ & $\begin{array}{l}\text { He found an automatic } \\
\text { wheelchair that can moved by } \\
\text { itself, he inserted the swearing } \\
\text { to break the spooky } \\
\text { atmosphere. }\end{array}$ \\
\hline 43 & $\begin{array}{c}\text { Okay, just } \\
\text { fucking great }\end{array}$ & $\begin{array}{l}00: 12: 49,000-- \\
>00: 12: 50,903\end{array}$ & $\begin{array}{l}\text { Not really } \\
\text { reffered the } \\
\text { matter } \\
\text { (Dr. Yate's } \\
\text { office) }\end{array}$ & $\begin{array}{l}\text { It's sarcasm that Pewds used in } \\
\text { the sitation }\end{array}$ \\
\hline 51 & What the shit? & $\begin{array}{l}00: 16: 59,149-- \\
>00: 17: 00,552\end{array}$ & $\begin{array}{c}\text { The sound he } \\
\text { heard } \\
\text { (Hospital } \\
\text { Entrance) }\end{array}$ & $\begin{array}{l}\text { He heard so many screaming } \\
\text { sound in the entrance when he } \\
\text { couldn't see anything at the } \\
\text { same time. }\end{array}$ \\
\hline 55 & $\begin{array}{c}\text { Where the } \\
\text { fuck do I go? }\end{array}$ & $\begin{array}{c}00: 17: 16,034-- \\
>00: 17: 17,502\end{array}$ & $\begin{array}{l}\text { Himself } \\
\text { (Hospital } \\
\text { Entrance) }\end{array}$ & $\begin{array}{l}\text { He's being chased by the } \\
\text { patient in the hospitals so he let } \\
\text { out swearing words to find the } \\
\text { exit door. }\end{array}$ \\
\hline 62 & Goddamn it & $\begin{array}{c}\text { 00:00:06,089 -- } \\
>00: 00: 011,960\end{array}$ & $\begin{array}{l}\text { Not really } \\
\text { reffered the } \\
\text { matter } \\
\text { (Living } \\
\text { room) }\end{array}$ & $\begin{array}{l}\text { He inserted the swearing words } \\
\text { when he mentioned another } \\
\text { series of Fridays with } \\
\text { PewDiePie, he used swearing } \\
\text { words to sound more informal, } \\
\text { so he's like just chit chat with } \\
\text { the viewers casually }\end{array}$ \\
\hline
\end{tabular}




\begin{tabular}{|c|c|c|c|c|}
\hline 63 & $\begin{array}{l}\text { shut the fuck } \\
\text { up you fucking } \\
\text { pussy }\end{array}$ & $\begin{array}{l}00: 01: 38,609-- \\
>00: 01: 41,610\end{array}$ & $\begin{array}{c}\text { Edgar; his } \\
\text { dog } \\
\text { (living room) }\end{array}$ & $\begin{array}{l}\text { The use of swear word 'shut } \\
\text { the fuck up' 'fucking pussy' } \\
\text { indicates that Pewds was } \\
\text { jokingly used the swear words } \\
\text { towards the dog as if he looked } \\
\text { angry but not mean it. }\end{array}$ \\
\hline 65 & $\begin{array}{l}\text { I'll fucking } \\
\text { stab a bitch! }\end{array}$ & $\begin{array}{l}00: 02: 41,568-- \\
>00: 02: 49,920\end{array}$ & $\begin{array}{c}\text { The } \\
\text { commenter } \\
\text { (living room) }\end{array}$ & $\begin{array}{l}\text { he was jokingly mentioned if } \\
\text { the viewers make fun of his } \\
\text { 'hare; he'll get revange which } \\
\text { is not true, he doesn't have any } \\
\text { hare at all. he inserted the } \\
\text { swearing to make the joke more } \\
\text { funny. }\end{array}$ \\
\hline 68 & $\begin{array}{l}\text { dude do they } \\
\text { write this with } \\
\text { our face or } \\
\text { some shit like I } \\
\text { don't } \\
\text { understand }\end{array}$ & $\begin{array}{c}00: 03: 48,674--> \\
00: 03: 51,847\end{array}$ & $\begin{array}{c}\text { The } \\
\text { commenter } \\
\text { (living room) }\end{array}$ & $\begin{array}{l}\text { He indicates that some of the } \\
\text { comment doesn't make sense, } \\
\text { he inserted the term 'some shit' } \\
\text { like increments of the } \\
\text { statement. }\end{array}$ \\
\hline 69 & $\begin{array}{l}\text { and then } \\
\text { wanting you to } \\
\text { suck their dick }\end{array}$ & $\begin{array}{l}00: 04: 01,071-- \\
>00: 04: 03,228\end{array}$ & $\begin{array}{l}\text { The } \\
\text { commenter } \\
\text { (living room) }\end{array}$ & $\begin{array}{l}\text { He rephrase the comment's of } \\
\text { the viewers cause it doesn't } \\
\text { match with his logic }\end{array}$ \\
\hline 71 & $\begin{array}{l}\text { that son of a } \\
\text { bitch. }\end{array}$ & $\begin{array}{l}00: 00: 53,460-- \\
>00: 00: 56,660\end{array}$ & $\begin{array}{c}\text { Jake } \\
\text { Paul;Youtube } \\
\text { rs } \\
\text { (his office) }\end{array}$ & $\begin{array}{l}\text { He found the other Yotubers } \\
\text { dissed him, so he inserted the } \\
\text { swearing to responsed them. In } \\
\text { this context, the meaning of } \\
\text { 'sun of bitch' is to reduce the } \\
\text { atmosphere of him being angry. }\end{array}$ \\
\hline $73,74,75$ & $\begin{array}{l}\text { Who the fuck } \\
\text { Is Jake Paul? }\end{array}$ & $\begin{array}{c}00: 01: 11,099-- \\
>00: 01: 13,479 \\
00: 01: 13,760-- \\
>00: 01: 15,800 \\
00: 02: 14,979-- \\
>00: 02: 16,019\end{array}$ & $\begin{array}{l}\text { Jake Paul; } \\
\text { Youtubers } \\
\text { (his office) }\end{array}$ & $\begin{array}{l}\text { one of Youtubers dissed } \\
\text { Pewdiepie,but Pewds doesn't } \\
\text { have any idea who JP is. He } \\
\text { has to know Jake Paul first } \\
\text { before juding the entire } \\
\text { controversy. He used it to } \\
\text { sound more dramatic but not in } \\
\text { serious tone. }\end{array}$ \\
\hline 79 & $\begin{array}{l}\text { J.P. You son } \\
\text { of a bitch! }\end{array}$ & $\begin{array}{c}00: 03: 21,379-- \\
>00: 03: 22,680\end{array}$ & $\begin{array}{l}\text { Jake Paul } \\
\text { (his office) }\end{array}$ & $\begin{array}{l}\text { He used it for funnier way the } \\
\text { expression whe he used the } \\
\text { swear words is not angry, but to } \\
\text { make it as a joke. }\end{array}$ \\
\hline 80 & $\begin{array}{l}\text { it's meant to } \\
\text { sound like } \\
\text { shit. }\end{array}$ & $\begin{array}{l}00: 03: 54,560-- \\
>00: 03: 59,140\end{array}$ & $\begin{array}{l}\text { JP's flow of } \\
\text { rap } \\
\text { (his office) }\end{array}$ & $\begin{array}{l}\text { It's sarcasm that pewd puts in } \\
\text { he's statement mean the new } \\
\text { form of rap is sound like JP }\end{array}$ \\
\hline 81 & booty back & $\begin{array}{c}00: 04: 21,649-- \\
>00: 04: 26,179\end{array}$ & $\begin{array}{l}\text { Not really } \\
\text { reffered the } \\
\text { matter } \\
\text { (his office) }\end{array}$ & $\begin{array}{l}\text { he make new rap flow to } \\
\text { replied JP's rap and he used } \\
\text { booty back means he likes a } \\
\text { girl who has larger butt than } \\
\text { her back. }\end{array}$ \\
\hline 82 & $\begin{array}{l}\text { it takes talking } \\
\text { shit on Twitter, }\end{array}$ & $\begin{array}{l}00: 04: 38,509-- \\
>00: 04: 43,519\end{array}$ & Rap flow & $\begin{array}{l}\text { He indicates that to make the } \\
\text { incredible flow, it takes so }\end{array}$ \\
\hline
\end{tabular}




\begin{tabular}{|c|c|c|c|c|}
\hline & $\begin{array}{l}\text { it takes all } \\
\text { kinds of sh- it } \\
\text { takes so much } \\
\text { shit- }\end{array}$ & & & much effort \\
\hline 83,84 & $\begin{array}{l}\text { I don't } \\
\text { understand } \\
\text { what the fuck } \\
\text { is happening } \\
\text { here is he } \\
\text { talking about } \\
\text { his ex or some } \\
\text { shit like that? }\end{array}$ & $\begin{array}{l}00: 05: 04,720-- \\
>00: 05: 05,653 \\
00: 05: 06,770-- \\
>00: 05: 08,913\end{array}$ & JP's rap & $\begin{array}{l}\text { He didn't understan what JP } \\
\text { said on his rap, so he guessed it } \\
\text { he talked about his ex. }\end{array}$ \\
\hline 86 & $\begin{array}{l}\text { Oh, he bitches } \\
\text { about his } \\
\text { girlfriend for } \\
\text { like-- for a } \\
\text { couple lines }\end{array}$ & $\begin{array}{l}00: 06: 01,220-- \\
>00: 06: 04,420\end{array}$ & $\begin{array}{l}\text { JP's rap line } \\
\text { (his office) }\end{array}$ & $\begin{array}{l}\text { Pewds think the rap didn't } \\
\text { make sense at first. the frist line } \\
\text { of the rap talked about his } \\
\text { girlfriend and then another line } \\
\text { he rapping about how rich he } \\
\text { was. He inserted the swearing } \\
\text { to sound jokingly adn not } \\
\text { brought it too serious. }\end{array}$ \\
\hline 87 & $\begin{array}{l}\text { you're } \\
\text { retarded }\end{array}$ & $\begin{array}{l}00: 07: 50,639-- \\
>00: 07: 52,819\end{array}$ & $\begin{array}{l}\text { One of JP's } \\
\text { crew } \\
\text { (his office) }\end{array}$ & $\begin{array}{l}\text { Pewd couldn't believe what he } \\
\text { saw, one of JP's crew rapping } \\
\text { was so terrible, so he swearing } \\
\text { at him. }\end{array}$ \\
\hline 90 & $\begin{array}{l}\text { This is so } \\
\text { fuckin' weird }\end{array}$ & $\begin{array}{l}00: 01: 56,400-- \\
>00: 01: 58,100\end{array}$ & $\begin{array}{l}\text { Camera } \\
\text { (Camera } \\
\text { no\#1 } \\
\text { (showed his } \\
\text { room) })\end{array}$ & $\begin{array}{l}\text { When he and Jack looked in the } \\
\text { camera he found himself a little } \\
\text { bit awkward, so he inserted the } \\
\text { swaring to break the } \\
\text { atmosphere. }\end{array}$ \\
\hline 91 & $\begin{array}{l}\text { Get that shit } \\
\text { away! }\end{array}$ & $\begin{array}{l}00: 02: 30,319-- \\
>00: 02: 32,539\end{array}$ & $\begin{array}{l}\text { The video he } \\
\text { watched } \\
\text { (Camera } \\
\text { no\#1 } \\
\text { (showed his } \\
\text { room)) }\end{array}$ & $\begin{array}{l}\text { He watched a gross video, so } \\
\text { he terrified by it and want to } \\
\text { get rid the video, he used the } \\
\text { swearing words means he } \\
\text { didn't want to looked the video } \\
\text { further. }\end{array}$ \\
\hline 95 & $\begin{array}{l}\text { what the } \\
\text { fuck?! }\end{array}$ & $\begin{array}{l}00: 04: 40,680-- \\
>00: 04: 42,660\end{array}$ & $\begin{array}{c}\text { Jack } \\
\text { (Camera } \\
\text { no\#1 } \\
\text { (showed his } \\
\text { room) }\end{array}$ & $\begin{array}{l}\text { He make sure what he heard } \\
\text { was right so he inserted the } \\
\text { swearing word to asked Jack } \\
\text { again in casual way. }\end{array}$ \\
\hline 104 & $\begin{array}{c}\text { What the } \\
\text { fuck? This } \\
\text { finale is killing } \\
\text { me }\end{array}$ & $\begin{array}{l}00: 08: 56,200-- \\
>00: 08: 59,360\end{array}$ & $\begin{array}{c}\text { The final } \\
\text { round } \\
\text { (Camera } \\
\text { no\#2 (down } \\
\text { on the floor)) }\end{array}$ & $\begin{array}{l}\text { The bolded senteces explained } \\
\text { that There's still no winner on } \\
\text { this round. }\end{array}$ \\
\hline
\end{tabular}




\section{c. Abusively}

From the displayed data in table 4.3, the writer found 1 swearing words which classified as abusive swearing out of $\mathbf{1 0 4}$ data swearing. It shows that abusive swearing is the least type of swearing words used in Pewdiepie's videos.

\begin{tabular}{|c|l|c|c|l|}
\hline \multirow{2}{*}{$\begin{array}{c}\text { Number } \begin{array}{c}\text { of } \\
\text { Datum }\end{array} \\
\text { 39 }\end{array}$} & \multirow{2}{*}{ Utterances } & Time you. & $\begin{array}{c}\text { Addressed } \\
\text { \& Setting }\end{array}$ & \multicolumn{2}{|c|}{ Topic } \\
\cline { 2 - 5 } & $00: 10: 55,019--$ & $\begin{array}{c}\text { One of the } \\
\text { patient in the } \\
\text { hospital } \\
\text { (Hospital } \\
\text { Entrance) }\end{array}$ & $\begin{array}{l}\text { He abusively used the } \\
\text { swearing cause he felt } \\
\text { threatening when one of } \\
\text { patient tried to approach } \\
\text { and scare him. }\end{array}$ \\
\hline
\end{tabular}

\section{d. Emphatically}

Based on table 4.4, the writer found 24 swearing words which classified as emphatic swearing out of 104 data. Because, datum 5,8 | 6,12 | 21,31,38,50 | 36,44 were quite similar and repetitious, the writer put each of them in the same collum. Kind of swearing words that are most used in Pewdiepie's video was swearing fuck there were 12, while swearing shit in the second place in total $\mathbf{8}$, while others like jesus christ and goddammit had the rest of it.

\begin{tabular}{|c|c|c|c|c|}
\hline \multirow{2}{*}{$\begin{array}{c}\text { Number } \\
\text { of } \\
\text { Datum }\end{array}$} & \multirow{2}{*}{ Utterances } & \multicolumn{3}{|c|}{ Context } \\
\hline & & Time & $\begin{array}{r}\text { Addressed } \\
\text { \& Setting }\end{array}$ & Topic \\
\hline 2 & $\begin{array}{l}\text { That is so } \\
\text { fucking } \\
\text { exciting! }\end{array}$ & $\begin{array}{l}00: 00: 49,062- \\
>00: 00: 51,219\end{array}$ & $\begin{array}{c}\text { Towards } \\
\text { himself } \\
\text { (living room) }\end{array}$ & $\begin{array}{l}\text { He emphasized his feeling by } \\
\text { inserting the swear word } \\
\text { fucking. }\end{array}$ \\
\hline 5,8 & $\begin{array}{l}\text { Jesus Christ } \\
\text { it's heavy }\end{array}$ & $\begin{array}{c}00: 01: 43,319-> \\
00: 01: 45,679 \\
00: 03: 20,520-> \\
00: 03: 22,040\end{array}$ & $\begin{array}{l}\text { The boxes } \\
\text { (living room) }\end{array}$ & $\begin{array}{l}\text { He emphasized the size of the } \\
\text { boxes by using swear words. }\end{array}$ \\
\hline 6,12 & $\begin{array}{l}\text { Holy shit guys, } \\
\text { OMG }\end{array}$ & $\begin{array}{c}00: 02: 46,099- \\
>00: 02: 50,799 \\
00: 04: 28,180-> \\
00: 04: 29,780\end{array}$ & $\begin{array}{c}\text { Open } \\
\text { expression } \\
\text { (living room) }\end{array}$ & $\begin{array}{l}\text { The bolded sentence indicates } \\
\text { that he was so happy about } \\
\text { the gift he recieved from } \\
\text { Youtube. He inserted } \\
\text { swearing to expressed the joy } \\
\text { expressions. }\end{array}$ \\
\hline 9 & $\begin{array}{l}\text { In my tiny, } \\
\text { shitty, fucking } \\
\text { flat in Sweden }\end{array}$ & $\begin{array}{c}00: 03: 39,919-> \\
00: 03: 43,439\end{array}$ & $\begin{array}{c}\text { The flat } \\
\text { (living room) }\end{array}$ & $\begin{array}{l}\text { The sentences describe } \\
\text { Pewd's condition before got } \\
\text { famous on youtube. He } \\
\text { explained the flat that he was } \\
\text { used to had by adding } \\
\text { swearwords to emphasize the } \\
\text { condition of the flat }\end{array}$ \\
\hline 15 & $\begin{array}{l}\text { a really fucked } \\
\text { up level. }\end{array}$ & $\begin{array}{c}00: 00: 23,189-> \\
00: 00: 24,757\end{array}$ & $\begin{array}{l}\text { The level of } \\
\text { the episode } \\
\text { (studio) }\end{array}$ & $\begin{array}{l}\text { The bolded sentences is To } \\
\text { emphasized what really } \\
\text { happened on this level }\end{array}$ \\
\hline
\end{tabular}




\begin{tabular}{|c|c|c|c|c|}
\hline 20 & $\begin{array}{l}\text { Why is it so } \\
\text { freaking hot? }\end{array}$ & $\begin{array}{l}00: 02: 41,460-- \\
>00: 02: 42,829\end{array}$ & $\begin{array}{l}\text { The weather } \\
\text { (hospital) }\end{array}$ & $\begin{array}{l}\text { To responsed the weather in } \\
\text { his situation by adding the } \\
\text { swearing to emphasize what } \\
\text { he really meant. }\end{array}$ \\
\hline $\begin{array}{c}21,31,38,5 \\
0\end{array}$ & Oh, shit! & $\begin{array}{c}00: 03: 32,544-- \\
>00: 03: 34,345 \\
00: 06: 49,141-- \\
>00: 06: 50,309 \\
00: 10: 26,323-- \\
>00: 10: 29,127 \\
00: 16: 51,509-- \\
>00: 16: 52,778\end{array}$ & $\begin{array}{l}\text { The situation } \\
\text { in hospital } \\
\text { (hospital } \\
\text { entrance) }\end{array}$ & $\begin{array}{l}\text { He walked in the hospital } \\
\text { entrance to find a clue for the } \\
\text { mission, he inserted the } \\
\text { swearing to revealed the } \\
\text { situation he felt, and showed } \\
\text { the express and excited } \\
\text { feeling at the same time. }\end{array}$ \\
\hline 25 & $\begin{array}{l}\text { What the } \\
\text { fuck? Is that }\end{array}$ & $\begin{array}{c}00: 04: 05,110-- \\
>00: 04: 07,045\end{array}$ & $\begin{array}{l}\text { The situation } \\
\text { in the } \\
\text { hospital. } \\
\text { (hospital) }\end{array}$ & $\begin{array}{l}\text { He explained the situation by } \\
\text { using swearing. The swearing } \\
\text { Indicates that he cofused over } \\
\text { the fact that the situation in } \\
\text { hospital was not what he } \\
\text { think it was }\end{array}$ \\
\hline 26 & $\begin{array}{l}\text { Are you } \\
\text { fucking } \\
\text { kidding me? }\end{array}$ & $\begin{array}{c}00: 04: 53,692-- \\
>00: 04: 55,127\end{array}$ & $\begin{array}{l}\text { Dr. Schwartz } \\
\text { (Hospital } \\
\text { room) }\end{array}$ & $\begin{array}{l}\text { He's in the room with the } \\
\text { doctor but the doctor tried to } \\
\text { handcuff him, so he swear } \\
\text { towards the doctor as if he } \\
\text { out of his mind. He } \\
\text { emphasized the word kidding. }\end{array}$ \\
\hline 36,44 & $\begin{array}{l}\text { What the fuck? } \\
\text { the room }\end{array}$ & $\begin{array}{l}00: 09: 14,052-- \\
>00: 09: 15,421 \\
00: 12: 57,642-- \\
>00: 12: 59,211 \\
\end{array}$ & $\begin{array}{l}\text { The room he } \\
\text { gets in } \\
\text { (Chapel } \\
\text { room) }\end{array}$ & $\begin{array}{l}\text { Pewds inserted the word fuck } \\
\text { as to describe the room in the } \\
\text { mission with confused face. }\end{array}$ \\
\hline 58 & $\begin{array}{l}\text { Fuck this } \\
\text { place! }\end{array}$ & $\begin{array}{c}00: 17: 26,076-- \\
>00: 17: 27,480\end{array}$ & $\begin{array}{c}\text { The hospital } \\
\text { (hopital } \\
\text { entrance) }\end{array}$ & $\begin{array}{l}\text { He described the hospital } \\
\text { was so messed. It meant that } \\
\text { his plan would not run } \\
\text { smoothly. Pewds inserted the } \\
\text { word fuck as an expression of } \\
\text { thrilled about an unexpected } \\
\text { situation. }\end{array}$ \\
\hline 59 & $\begin{array}{l}\text { Where the } \\
\text { fuck is the } \\
\text { exit? }\end{array}$ & $\begin{array}{c}00: 17: 27,890--> \\
00: 17: 29,905\end{array}$ & $\begin{array}{c}\text { The exit door } \\
\text { (hospital) }\end{array}$ & $\begin{array}{l}\text { He inserted the swearing to } \\
\text { emphasize where the exit } \\
\text { door was. }\end{array}$ \\
\hline 67 & $\begin{array}{l}\text { that's fucking } \\
\text { hardcore }\end{array}$ & $\begin{array}{c}00: 03: 33,719--> \\
00: 03: 34,699\end{array}$ & $\begin{array}{c}\text { The } \\
\text { commenter } \\
\text { (living room) }\end{array}$ & $\begin{array}{l}\text { He emphasizes the word } \\
\text { hardcore, when he read a } \\
\text { mean cooments. He inserted } \\
\text { the swearing to conviced his } \\
\text { statement }\end{array}$ \\
\hline 70 & $\begin{array}{lr}\text { that's } & \text { gay } \\
\text { that's } & \text { really } \\
\text { really } & \text { fucking } \\
\text { gay } & \end{array}$ & $\begin{array}{c}00: 04: 03,701-- \\
>00: 04: 06,976\end{array}$ & $\begin{array}{c}\text { The } \\
\text { commenter } \\
\text { (living room) }\end{array}$ & $\begin{array}{l}\text { He emphasizes the word gay } \\
\text { by inserting the swearing to } \\
\text { make sure that the commenter } \\
\text { can acknowledge he's } \\
\text { statement }\end{array}$ \\
\hline
\end{tabular}




\begin{tabular}{|c|c|c|c|c|}
\hline 76 & $\begin{array}{l}\text { I'm glad we got } \\
\text { the whole } \\
\text { Disney } \\
\text { Channel thing } \\
\text { out of the way } \\
\text { from the first } \\
\text { fucking line. }\end{array}$ & $\begin{array}{c}00: 02: 27,259-- \\
>00: 02: 32,859\end{array}$ & $\begin{array}{c}\text { Disney } \\
\text { (his office) }\end{array}$ & $\begin{array}{l}\text { The bolded sentences } \\
\text { indicates that now he grateful, } \\
\text { he free from disney drama, } \\
\text { and he inserted swearing to } \\
\text { emphasize that he grateful he } \\
\text { was out from disney befire it } \\
\text { get worse. }\end{array}$ \\
\hline 99 & $\begin{array}{c}\text { That fucking } \\
\text { counts! }\end{array}$ & $\begin{array}{l}00: 06: 15,420 \\
>00: 06: 19,020\end{array}$ & $\begin{array}{c}\text { Jack } \\
\text { (Camera } \\
\text { no\#2 (down } \\
\text { on the floor)) }\end{array}$ & $\begin{array}{l}\text { The bolded sentences } \\
\text { indicates that he still winning } \\
\text { the challenge even though } \\
\text { Jack questioning his winning, } \\
\text { but he } \\
\text { emphasized that it still counts } \\
\text { and he still win the round. }\end{array}$ \\
\hline 100 & 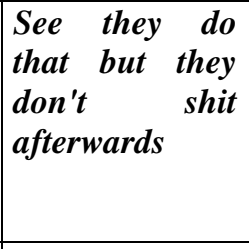 & $\begin{array}{l}00: 06: 37,180-- \\
>00: 06: 39,680\end{array}$ & $\begin{array}{l}\text { Pewd's frog } \\
\text {;slippy } \\
\text { (Camera } \\
\text { no\#1 } \\
\text { (showed his } \\
\text { room)) } \\
\end{array}$ & $\begin{array}{l}\text { The video showed a frog } \\
\text { croaking, so Pewds explained } \\
\text { if they did that they don't } \\
\text { feces afterwards }\end{array}$ \\
\hline 103 & Goddammit! & $\begin{array}{c}00: 08: 05,620-- \\
>00: 08: 06,959\end{array}$ & $\begin{array}{c}\text { The situation } \\
\text { of the } \\
\text { mission } \\
\text { (Camera } \\
\text { no\#2 (down } \\
\text { on the floor)) }\end{array}$ & $\begin{array}{l}\text { Jack and Pewds challenge } \\
\text { theyself to do flip bottle } \\
\text { challenge, this round they } \\
\text { both winning and showed joy } \\
\text { expression but the round still } \\
\text { continued. } \\
\text { They inserted the swearing to } \\
\text { express joy and funny feeling. }\end{array}$ \\
\hline
\end{tabular}

\section{e. Cathartically}

Based on table 4.4, the writer found 27 swearing words which classified as cathartically swearing out of $\mathbf{1 0 4}$ data swearing. The table above had so many similar and repetitious data which put them in the same collum $\mathbf{1 , 1 9 , 7 8 , 8 9}|\mathbf{2 3 , 4 7 , 4 9 , 9 2}|$ $\mathbf{3 4 , 4 1 , 4 8 , 5 0 , 5 3 , 5 6 , 5 7}|\mathbf{4 2 , 5 2 , 6 0 , 9 4}| \mathbf{9 6 , 9 8}$. The writers found that cathartically swearing is the second types of swearing words that most used in Pewdiepie's videos.

\begin{tabular}{|c|c|c|c|c|}
\hline \multirow{2}{*}{$\begin{array}{l}\text { Number } \\
\text { of } \\
\text { Datum }\end{array}$} & \multirow{2}{*}{ Utterances } & \multicolumn{3}{|c|}{ Context } \\
\hline & & Time & $\begin{array}{c}\text { Addressed } \\
\text { \& Setting }\end{array}$ & Topic \\
\hline $\begin{array}{l}1,19 \\
78,89\end{array}$ & Goddammit! & $\begin{array}{c}00: 00: 26,059- \\
>00: 00: 27,279 \\
00: 02: 34,152-> \\
00: 02: 36,121 \\
00: 03: 19,020-- \\
>00: 03: 19,840 \\
00: 01: 53,040--> \\
00: 01: 54,460\end{array}$ & $\begin{array}{l}\text { The emotion } \\
\text { he feels } \\
\text { (living room; } \\
\text { hospital;his } \\
\text { office) }\end{array}$ & $\begin{array}{l}\text { The bolded sentences } \\
\text { indicates that he used swear } \\
\text { word expression for being } \\
\text { nervous and to calm himself } \\
\text { of what will happened next. }\end{array}$ \\
\hline 7 & $\begin{array}{l}\text { OMG Fuck } \\
\text { Fuck jesus }\end{array}$ & $\begin{array}{c}00: 03: 09,780-> \\
00: 03: 14,160\end{array}$ & $\begin{array}{l}\text { The boxes } \\
\text { (living room) }\end{array}$ & $\begin{array}{l}\text { When he lifted the heavy } \\
\text { boxes he inserted the } \\
\text { swearing, and decided to use }\end{array}$ \\
\hline
\end{tabular}




\begin{tabular}{|c|c|c|c|c|}
\hline & & & & $\begin{array}{l}\text { a distasteful style of } \\
\text { language. }\end{array}$ \\
\hline 18 & $\begin{array}{l}\text { What the } \\
\text { fuck? }\end{array}$ & $\begin{array}{c}00: 01: 18,578-> \\
00: 01: 21,213\end{array}$ & $\begin{array}{l}\text { The girl } \\
\text { (in the car) }\end{array}$ & $\begin{array}{l}\text { [Cut of the previous episode] } \\
\text { when the girl suddenly appear } \\
\text { in his car, he let out swearing } \\
\text { to expressed his shocked and } \\
\text { surprised. }\end{array}$ \\
\hline $\begin{array}{c}23,47,49,9 \\
2\end{array}$ & Oh! Fuck! & $\begin{array}{c}00: 03: 50,194-- \\
>00: 03: 51,830 \\
00: 15: 40,405-- \\
>00: 15: 41,539 \\
00: 16: 07,732-- \\
>00: 16: 09,400 \\
00: 02: 44,099-> \\
00: 02: 44,599\end{array}$ & $\begin{array}{l}\text { The person } \\
\text { who suprised } \\
\text { him } \\
\text { (hospital } \\
\text { entrance) }\end{array}$ & $\begin{array}{l}\text { He response the shocked } \\
\text { feelings when a man } \\
\text { surprised him in the back, or } \\
\text { when he saw something bad } \\
\text { happened. }\end{array}$ \\
\hline 32 & Fuck me. & $\begin{array}{l}00: 07: 02,454-- \\
>00: 07: 03,723\end{array}$ & $\begin{array}{l}\text { The keys } \\
\text { (Hospital } \\
\text { room) }\end{array}$ & $\begin{array}{l}\text { The bolded sentences } \\
\text { indicates that he's so stressed } \\
\text { that he let out swearing cause } \\
\text { he had to find the original key } \\
\text { so he could released himself } \\
\text { from the handcuff. }\end{array}$ \\
\hline $\begin{array}{l}\mathbf{3 4 , 4 1 , 4 8 , 5} \\
\mathbf{0 , 5 3 , 5 6 , 5 7}\end{array}$ & Shit!. & $\begin{array}{c}00: 08: 21,065-- \\
>00: 08: 23,401 \\
00: 11: 41,399-- \\
>00: 11: 43,668 \\
00: 15: 47,611-- \\
>00: 15: 48,746 \\
00: 16: 51,509-- \\
>00: 16: 52,778 \\
00: 17: 10,628-- \\
>00: 17: 12,529 \\
00: 17: 17,568-- \\
>00: 17: 18,903 \\
00: 17: 22,507-- \\
>00: 17: 23,741\end{array}$ & $\begin{array}{l}\text { Open } \\
\text { expression. } \\
\text { (hospital } \\
\text { entrance) }\end{array}$ & $\begin{array}{l}\text { The bolded word, "Shit" } \\
\text { indicates that Pewds was } \\
\text { panic and upset. When } \\
\text { something bad happended or } \\
\text { it's unpredictable Pewds tend } \\
\text { to use swearing like "shit" to } \\
\text { express his feelings. }\end{array}$ \\
\hline $\begin{array}{c}42,52,60,9 \\
4\end{array}$ & Jesus Christ! & $\begin{array}{c}00: 12: 16,567-- \\
>00: 12: 17,635 \\
00: 17: 06,057-- \\
>00: 17: 08,660 \\
00: 17: 34,486-> \\
00: 17: 36,789 \\
00: 03: 09,020--> \\
00: 03: 10,700\end{array}$ & $\begin{array}{c}\text { Open } \\
\text { expression of } \\
\text { how he felt } \\
\text { (Hallway;his } \\
\text { office) }\end{array}$ & $\begin{array}{l}\text { The swear word expression, } \\
\text { Jesus Christ, used to express } \\
\text { an confusing situation that } \\
\text { Pewds faced. }\end{array}$ \\
\hline 64 & $\begin{array}{l}\text { wait a minute, } \\
\text { what that fuck }\end{array}$ & $\begin{array}{c}00: 01: 42,170-- \\
>00: 01: 48,739\end{array}$ & $\begin{array}{c}\text { The } \\
\text { comments he } \\
\text { read } \\
\text { (living room) }\end{array}$ & $\begin{array}{l}\text { He found the same } \\
\text { conspiration of his dog and } \\
\text { the commenter, he let out } \\
\text { swearing words as shocked } \\
\text { emotion he felt }\end{array}$ \\
\hline
\end{tabular}




\begin{tabular}{|c|c|c|c|c|}
\hline 77 & $\begin{array}{l}\text { Fuck, I got the } \\
\text { shakes again. }\end{array}$ & $\begin{array}{c}00: 03: 16,659-- \\
>00: 03: 19,020\end{array}$ & $\begin{array}{l}\text { Jake Paul } \\
\text { (his office) }\end{array}$ & $\begin{array}{l}\text { The bolded sentenences } \\
\text { indicates that his dibelief of } \\
\text { what he saw with his own } \\
\text { eyes that Jake Paul dissed } \\
\text { him. }\end{array}$ \\
\hline 96,98 & $\begin{array}{l}\text { Ohh, what the } \\
\text { fuck? }\end{array}$ & $\begin{array}{l}\text { 00:05:05,360 -- } \\
>00: 05: 07,180 \\
00: 05: 55,899-- \\
>00: 05: 58,339\end{array}$ & $\begin{array}{l}\text { The video he } \\
\text { watched } \\
\text { (Camera } \\
\text { no\#1 } \\
\text { (showed his } \\
\text { room)) }\end{array}$ & $\begin{array}{l}\text { He didn't believe what he } \\
\text { saw was real, he inserted } \\
\text { swearing as disbelief } \\
\text { expression of what he saw. }\end{array}$ \\
\hline 97 & $\begin{array}{l}\text { Fuck! I don't } \\
\text { wanna }\end{array}$ & $\begin{array}{c}00: 05: 39,560-- \\
>00: 05: 40,720\end{array}$ & $\begin{array}{l}\text { The terrified } \\
\text { feeling } \\
\text { (Camera } \\
\text { no\#1 } \\
\text { (showed his } \\
\text { room)) }\end{array}$ & $\begin{array}{l}\text { He was so thrilled to even } \\
\text { open another weird video } \\
\text { again but he had to. He } \\
\text { inserted } \\
\text { expressed } \\
\text { feelings. }\end{array}$ \\
\hline 102 & Fuck! & $\begin{array}{c}00: 07: 38,040 \rightarrow \\
00: 07: 38,540\end{array}$ & & $\begin{array}{l}\text { He failed to flip the bottle, he } \\
\text { let out swearing to expressed } \\
\text { his anger. }\end{array}$ \\
\hline
\end{tabular}

\section{DISCUSSION}

There are five types of swearing words used in Pewdipie's Youtube Videos based on Pinker's theory (2007). They are dysphemism, idiomatically, abusively, emphatically, cathartically. Each of them is explained one by one followed by some examples.

a. Dysphemism \& Idiomatically

Dysphemism becomes in the fouth place that is the most used by Pewdiepie in his video. Dysphemism is the use of a harsh, more offensive word instead of one considered less harsh and often contrasted with euphemism (polite expression used in place of words or phrases that otherwise might be considered harsh or unpleasant to hear) (pinker, 2007:323). So, this kind of swearing are generally used to shock or offend the hearer. Dysphemism and idiomatic swearing somehow have same reference but both are different. The distinction between dysphemism and idiomatic is related to the level of offensive. Dysphemism is believed to be prohibited from public use since they involve repulsion to the sense, abhorrent, impolite and detestable to morality.

In PewDiePie's videos, dysphemism appears 14 times and two of them are presented below.

Patients in the entrance: Where's Schwartz? Where's Schwartz? [whispering]

Pewdiepie: What the fuck are you? [towards the patient]

(Datum no.40)

The background of the dialogue above is like this, Pewds was ready to find his room and a clue for the mission, but in the hospital entrance there were so many crazy 
patients that tried to approch him, Pewds was startled and started swearing towards one of the patient who suddenly aproach him. The word fuck is included into dysphemism swearing. According to Allan and Burridge (2006) Dysphemism is a swearing expression that are offensive either about the environment or the audience, or both and it is substituted for a neutral or euphemistic expression for just that reason.

Therefore, based on Pinker (2007) and Allan (2006) theories the dialogue above contains dysphemism type. Pewds used the phrase of 'who the fuck are you' to address the Patient in procative manner, an annoying patient who made him scared, which caused him to get angry. Instead he used "who are you" he add the f- word in the middle. Moreover, that word can trigger disgust to the sense so that it is highly restricted for public use. In line with Holmes' theory of social dimension (An Introduction to Sociolinguistics, 2001:12), the relationship between participants and the status of a speaker and a hearer can influence word choice. The relationship between Pewds and Patients who always buging him has created bad atmosphere of their psychological setting. Dennis as a main youtuber felt that he has a power to manage all happens in his video. He showed his ability by using the swear word as a harsh attitude for the patient.

Differs from another types, in pewdiepie's videos there is also similar phrase that repertitious but it used in different context, idiomatic swearing also has the same phrase like:

What the fuck is this? (datum number 3, and 4) (Ruby Playbutton

Who the fuck Is Jake Paul? (datum 73,74) (Pewdipies video: Jake Paul)

The dialogue above happened when Pewdiepie was in his room (datum 3,4) and in his office studio (datum 73,74). In datum 3,4, Pewds tried to open the box that Youtube give him while in datum 73,74 one of Youtubers dissed Pewdiepie, but Pewds doesn't have any idea who JP was. He had to know Jake Paul first before juding the entire controversy.

It could be noticed in the bolded words "What the fuck is this? Who the fuck Is Jake Paul?" indicates that Pewds used this in order to make it casual and more like a joke so the viewers didn't take that as negative expressions. Idiomatic swearing according to Pinker (2007) is a type of swearing where words are used to capture a person's attention, exude coolness or to express to peers that the person who is involved in swearing and his or her audience are in an informal setting. It's clear that Pewd used the swearing above to make it lessformal, because he records his video in his own living room which basically mean he can have used the swearing whanever he can, and to emphasis the viewers that 'this is not some serious event/things'.

The dialogue above has the same vibes (datum no. 40) but the difference between both of them is from the context of the swearing itself. Datum no 40 it's clear that is dysphemism, directed towards the patient and Pewds was angry at that time, its 
somehow led to procative manner while datum 3,4 and73, 74 it's not because Pewd used the sweearing without really reffering the matter, he used this to make the video lessformal, and to attract the viewers. Idiomatic swearing is more used in a casual setting. It's not negative in context but expresses a closeness with other. It's the kind of swearing people use around friends or some places when it's unnecessary. Both function of the swearing is different.

While swearing dysmpemism is in the fourth place, idiomatic swearing has to be the most widely used in Pewdiepie's videos with total 38 out of 104 swearing data.

b. Idiomatic Swearing

Idiomatic swearing becomes in the first place that is the most used by Pewdiepie in his video. According to Pinker's theory (2007) Idiomatic swearing Is swearing without really referring to the matter, and it is used to gain attention, or to arouse interest in a certain matter. It can be seen as follows:

Pewds: You're about to watch me get the absolute shit scared out of me.

[datum no. 14]

The scene takes place in PewDiePie's studio where there so much camera and stuff it means that he used that by on purpose. The bolded sentence indicates that Pewds used the swearing to make the viewer attract and wanted to wach his video. The phrase shit out of me indicates that there so much frigthened scene and his pomise the viewers that they wil be scared if they watched his video. He says the word 'shit scared' in a medium intonation; the word 'shit' means excrement; to defecate; the act or instance of defecating. In swearing 'shit' used to express disgust or disappointment. It relates with sexuality term, in contrast, in this video, it is used for different context. It is used to express his excitement. In this case, the word 'shit' as followed by 'scared out of me' will have positive meaning and also used in emotional reaction. It is used to gain the attention of the viewer to share the excitement of his sentence.

The purpose of using swear word is not to offend viewer as a hearer. It is commonly used in western culture especially in Englad where people there usually used swear words without offensive and for reducing tension so that the conversation seems more relaxed and less formal.

In line with Holmes's theory (2001), Pewds uses swear word for reducing tension since he has to make the video less scary. The use of swear word is also influenced by the background of the participant. In this context, Pewdiepie who always deal with swear words. His job also influences his language style, since he should follow what trend now in which people usually use bad language, including using the swear word.

c. Abusive swearing

Abusive swearing becomes the the least type of swearing words used in Pewdiepie's videos. In Pewdiepie's videos, abusive swearing appear 1 times out of 104 swearing data. Abusive swearing occurs purely for the intention of intimidating 
or insulting the other person (Pinker: 2007). Often used in moments of anger or revenge such as fuck you!, fuck off, moherfucker, son of bitch, shithole, cunt. The intention of the speaker is actually to express an emotional reaction to certain stimuli. In this analysis, the most common abusive swearing used in the Pewdipie's videos are fuck and bitch. An example of abusive swearing can be seen as follows.

Sound from the wheelchair :I'm gonna take you somewhere real fun.

Pewds: Oh, come on. [man screaming] Where are we going?

Sound from the wheelchair: I'm gonna take you somewhere real fun.

Pewds: [gasps] Okay, okay. That's just great. [some patient aproach him] Fuck you!

[datum no.39]

The datum above is a dialogue between man behind the sound of wheelchair and Pewds. At that time, Pewds asked where he was heading but in the midle of the scene someone intrigued his conversation and surprised him, so Pewds took a revenge and start swearing to him. This psychological setting made him could not control his emotion. This explanation is in line with Hymes' theory (Foundation in Sociolinguistics: An Ethnographic Approach,1974: 61) that a psychological setting and norm of interpretation influence word choice, including inserting a swear word in a conversation.

Let's take a look at the bolded sentence "Fuck you!" The word 'fuck you' indicates that Pewds was very angry and he did not want to be managed by anyone. In this context, the funtion of 'fuck you' is an intention to give a warning to one of the patient not to get involved in Pewd's business. From the analysis, the swear word 'fuck you' has an abusive meaning.

d. Emphatic Swearing

Emphatic swearing becomes in the third place that is most used type of swearing words in Pewdiepie's videos with total 24 times appears out of 104 swearing data from appendix. Emphatic swearing based on pinker's (2007) occurs when the speakers used to add emphasis to what the speakers are saying. Nevertheless, in Pewdipie's videos case, some line, or phrase that catogorize as emphatic swearing are from the excited expression or emphatic expression. Here is an example of emphatic swearing that disclaimed as an excited expression in Pewdiepie's videos.

Pewdiepie: Holy shit $\boldsymbol{O M G}$ *still in shock* you won't believe this, look how much bubble wrap! *pops some bubble wrap* oh I love it! Hours of entertaiment. lets open the box.

[datum no. 6,12]

Pewds was trying to open the box, that Youtube give him as an awards from being the most subscribers channel, so he actually pretty excited to open the box. After Pewds open the first box, he couldn't hide his feeling and let out swearing. 
Let us pay attention to the bolded sentence, "Holy shit OMG!" The use of swear word 'holy shit' indicates that Pewds was excited so that he showed his quircky attitude by showing his expression as Holy shit. But in pinker's theory he's not mentioned that showing excited feelings are considered as Emphatically, but this context helped by Kristy (2012:105) theories that said the emphatic swearing refers to swearing utterances made in a tone of insistence, emphatic, excited or anecdotal manners, without subtantial trace of any other tone. No annoyance or stress could be detected in swearing utterances which were judged to be emphatic, excited or anecdotal. Another example of emphatic swearing found in Pewdiepie's video can be seen from the conversation between Pewds and his friend Jack.

Pewds: [the bottle flip] I am the one! Okay! [jack successfully flip the bottle too] Nooo! Noooo!

Jack: Yeaaahehehehahahahahahaah

Pewds: OK, It continues, It continues

Jack: Okay

Pewds: Oooohh! [success flip the bottle]

Jack: Ohhohhhooo! [but Jack also success]

Pewds: Noooo! [both laughs] Goddammit! [laugh]

[datum no. 103]

When the dialogue happened, Pewds and his partner, Jack, played a flip bottle challenge after so many round they both still couldn't be the winner, they always tie. Pewds successs to flip the bottle but in minutes Jack success to flip it too. So they both laughing, in result Pewd let out swearing to showed the happy and excited emotions. The bolded sentence, "God dammit" indicates that Pewds actually very excited based on how he used the swearing with the happy tone. Instead of using the words politely like 'Oh God' he prefered inserting a swear word to respon Jack's winning by using the sentence 'God dammit'. However, it did not offend Jack's feeling. It was because he had known that Pewds had a tempramental attitude and he often used swear words when he had a conversation with others.

From all the analyses above, the conclusion that can be drawn is "Emphatic swearing add emphasis to what we are saying" that statement is true, but this 'emphasis' creates a stimulating atmosphere, which is why the use of swearing works so comfortably in casual atmospheres; people in a casual situation may be having a great time without having to worry about offending anyone or committing as many linguistic crimes. In this case, emphatic swearing such as, "shit OMG" or "Goddammit" does not feel out of place or inappropriate. The swear word simply emphasizes the phrase that would otherwise say the same thing. Emphatic Swearing can be quite effective and truly drive the meaning of emotion behind the swear word.

e. Cathartic Swearing

Crathartically becomes the second most used type of swearing words with total 27 time appears out of 104 swearing data. Cathartic swearing can occur because the one who utters the word is motivated by frustration, pain, stress or anger. 
Therefore, people will use emotional language by uttering the swearing words which aimed because of there is reason. In Pewdiepie's video, emphatic swearing is shown in words like shit and Fuck or even Jesus Christ which characterize the use of offensive term. Here is an example of Cathartically in Pewdiepie's Youtube videos.

Pewds: [flip the bottle] I dont have the technique down yet

Jack: Yeah I dont- I dont get it.. [fail to flip the bottle] don't let it- it's an arc

Pewds: Ohhhh!

Jack: *Whines*[flip the bottle]Yeahhes [the bottle flip]

Pewds: I still- Theres still hope [fail to flip the challenge] [jack win]

Jack: *singing* I am the one don't weigh a ton!! camera 1! [stand up]

Pewds: Okay, Camera 1. Okay, Oh it's my turn. Fuck! I don't wanna

[datum no. 97]

The conversation contains emphatic as one of the types of swear words because Pewds utters the word Fuck which refers to frustration. It helped by pinker's (2007) statement that said, the sudden activation of the system when confronted with pain or frustration may have a cathartic effect as a by-product. Moreover, the swear word Fuck in an utterance is used to refer to a frustation, scare or any particular difficult situation. In this context Pewdipie was frustated because he lose the challenge to Jack, and the loser would get punishment such us watched some gross videos, he lose so he had to took the consequences, he let out swearing 'Fuck, I don't wanna' as an open emotion of being stressed. Jeff uses the swear words to offend the man as a hearer. According to Holmes' theory of social dimension (An Introduction to Sociolinguistics, 2001:12-14), both participants do have an intimate relationship; their relationship is as bestfriend. It makes his intonation and words choice different from formal language. Pewds uses swear words to express frustation, and disappointment feeling because of his psychological setting that is under pressure.

From the explanation between Cathartic and Emphatic swearing, both of them is really opposite from each others. Emphatically done with the intention to place emphasis on something or a situation, while Cathartic swearing occurs when someone is expressing and alleviating pain, frustration, stress, or regret. Both very difference yet some of the phrases are very similar. The writer found some phrases that quite similat but it categorized as different types. Here is an example for both Cathartic and Emphatic swearing that are similar:

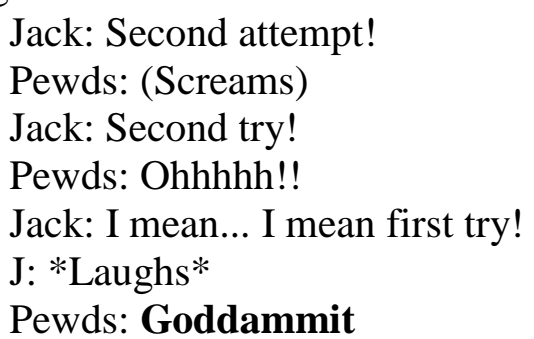

[datum no. 89] 
It is clear that the example above shows that Pewds utters the word God dammit which is categorized as Cathartic swearing. The word dammit is a slang, and by adding a religious word to it, is necessarily offensive to those who believe in the relegion. Although the terminology is used with those manners, but the intention of the speaker is not actually to denigrate God or anything associated with religion. The swearing itsef occurs from the open expression of being frustated. That conversation occurs after Pewds and Jack both played flip bottle challenge in the end Pewds lose so he leat out swearing to release his anger. But what if some word like 'God dammit' have different context and it becomes different types. This case happened in Pewdiepie's vdeos too. In datum no. 103 that have already explained in analysis of emphatic swearing. It shows that even though Pewdiepie used similar swear words but if he used in different context, the types of swearing can also change.

From all the analyses above, the conclusion that can be drawn is the use of swear word is influenced by the evinronment, relationship or event between the user, the degree of formality and psychological setting when the swearing happens. In these analyses, when the user has a something that annoy him or without even some factors, they often use swear word for expressing his negative condition such as being angry, dissapointment, excited, or even just to make it more cool to hear. However, when the participants have a friendship relationship, the use of swear word can cause the conversation more relax and less formal. Commonly, the use of swear word has a negative purpose that is to offend the hearer. However, in these analyses, the fuction of using swear word is for reducing tension and it can also be used as an identity of a certain group.

\section{CONCLUSIONS}

The first objective of this research is to identify and to describe the types of swear words in Pewdiepie's Youtube videos. All the five types of swear words that consist of dysphemism, idiomatic, abusive, emphatic and carthartic swearing appear in the videos. The most used of the types of swear words is Idiomatic swearing. Idiomatically appears 38 times out of 104 total data. The lowest score is obtained by Abusively with only 1 data.

Idiomatically becomes the most used swear words because it is considered as the most effective way to attract the viewers without offend them. Moreover, idiomatically type is frequently used by the Pewdiepie when he wanted to make it more casual, non-awkward and to sound fun. By using idiomatic swearing that have no-referential meaning, the speaker can easily attract the attention of the viewers. The least type of swear words used in Pewdiepie's videos is Abusive and Dypshemism. Therefore, it can be noticed that abusive and diyphemism is not effective enough to be used because it can offend the viewers and debase other people's pride. Instead of using abusive as offensive language, Pewdiepie use idiomatic and emphatic swearing to draw viewer's attention by calling one's name with a certain type of slurs such as a word that refers to sexuality. 


\section{REFERENCES}

Allan, K. and Burridge, K. Forbidden Words: Taboo and the Censoring of Language. New York: Cambridge University Press, 2006.

Andersson, L.G and P Trudgill. "Swearing." L, Monaghan and Goodman J. A Cultural Approach to Interpersonal Communication. UK: Blackwell: Oxford, 2007. 195-199.

Andersson, Lars- Gunnar and Peter Trudgill. Bad Language (Penguin Language \& Linguistics). Mishawaka: Penguin, 1992.

Anthony McEnery, Zhonghua Xiao. Swearing in Modern British English: The Case of Fuck in the BNC. Penguin, 2004 .

B, Crecente. "PewDiePie isn't just a popular Let's Play YouTuber, he's the \$4M-ayear king of YouTube." 2014. http://www.polygon.com/2014/6/17/5817118/how-much-does-pewdiepiemake.

B, Kristy. Who's Swearing Now? The Social Aspects of Conversational Swearing. 12 Back Chapman Street, Newcastle upon Tyne: Cambridge Scholars Publishing, 2012. British Library.

Baruch, Y and S Jenkin. "Swearing at work and permissive leadership culture: When anti-social becomes social and incivility is acceptable." Leadership \& Organization Development Journal (2007): 492-507.

Biklen, Bogdan and. Qualitative Research for Education: an Introduction to Theory and Method. Boston: Allyn and Bacon Inc, 1992.

C, Hall. " PewDiePie 'more influential' among teens than Katy Perry and Hollywood elite." 2014. http://www.polygon.com/2014/8/7/5980019/pewdiepie-morepopular-amongteens-than-traditional-celebrities.

Chrystal, D. The Cambridge Ensyclopedia of The English Language 2nd Edition. USA: University of Cambridge Press, 2003.

Crystal, David. English as a global language. Cambridge: Cambridge University Press, 2003.

Fairman, C. Fuck. Public Law and Legal Theory Working Paper Series, 2006. 59.

Fairman, C. M. Fuck. Retrieved April 21st, 2012: From: (http://ssrn.com/abstract=896790), 2006.

Henry, Gary T. Practical Sampling. Vanderbilt University: SAGE Publications, Inc, 1990.

Holmes, Janet. An Introduction to Sociolinguistics. London: Longman, 2001.

Howe, R. The use of Fuck: A sociolinguistic approach to the usage of Fuck in the $B N C$ and Blog Authorship Corpus. Ypsilanti, MI, USA: Eastern Michigan University, 2012.

Hymes, D. On Communicative Competence In J. Pride and J. Holmes. 1972.

J, Lyons. Language and Linguisics: An Introduction. England: Cambridge University, 1981. 
Jay. 2,170 Obscene words. Who, what, where, when. New York: Eastern Psychological Association, 1986.

Johnson, F. \& Fine, G. "Sex differences in uses and perceptions of obscenity." Women's Studies in Communication (1985): 11-24. . 8.

Karjalainen, M. "Where have all the swearwords gone?" Analysis of the loss of swearwords in two Swedish translations of J.D Salinger"s Catcher in the Rye3007,2002. http://www.etheis.helsinki.fi/.ulkasi/engla/pa/karjalainen.pdf.

Kristy, B. Who's Swearing Now? The Social Aspects of Conversational Swearing. 12 Back Chapman Street, Mewcastle upon tyne, NE6 2XX, UK: cambridge scholars publishing, 2012.

Ljung, Magnus. Swearing: A Cross-Cultural Linguistic Study. . Houndmills, Basingstoke: Palgrave Macmillan, 2011.

Michael, S. Practical English Usage. New York: Oxford Up, 1995.

Miles, MB. \& Huberman, AM. Qualitative Data Analysis (2nd edition). Thousand Oaks, CA: Sage Publications., 1994.

Montagu, Ashley. The Anatomy of Swearing. U.S.A: University of Pennsylvania Press, 1967.

Nerbonne, G. \& Hipskind, M. "The use of profanity in conversational." Journal of Communication Disorders (1972): 47-50. 5.

Paolillo, J. C. "Structure and network in the YouTube core." Annual Hawaii International Conference on System Sciences. 2008.41. http://www.computer.org/portal/web/csdl/doi/2010.1109/HICSS.2008.2415 .

Patricia, G. Lange. Searching for the 'You' in 'YouTube': An Analysis of Online Response Ability. California: University of Southern California, 2007.

Pinker, S. The stuff of thought: Language as a window into human nature. New York,: Penguin, 2007.

Kn.d - The stuff of thought: Language as a window into human nature. New York: Penguin, 2007.

Piolat, A., \& Boch, F. (). "Apprendre en notant et apprendre a noter." Learning by taking notes and learning to take notes. Ed. \& P. Dessus E. Gentaz. Paris: Dunod: Psychologie cognitive et e'ducation, 2004. 133-152.

Rassin, E and Der Heijden Van. "Appearing credible? Swearing helps!" Psychology, Crime, \& Law (2005): 177-182.

Rassin, E and P Muris. "Why do women swear? An exploration of reasons for and perceived efficacy of swearing in Dutch female students. ." Personality and Individual (2005): 1669-1674.

Sheth, A. P. "Cursing in English on Twitter." ACM Conference on Computer Supported Cooperative Work \& Social Computing (2014): 415-424.

Simonsen, T.M. Categorising YouTube. Denmark: SMID, 2011. 